\title{
The IRI and Its Swedish Connection
}

\section{Benny Carlson}

Lund University

\begin{abstract}
The story of the International Industrial Relations Institute (IRI), its de facto leader Mary van Kleeck from the United States and its first chairman Kerstin Hesselgren from Sweden begins in 1925, when the IRI was established at a congress for welfare and personnel workers in Holland. At first the organization was focused on scientific management and industrial relations but during the Great Depression its activities began revolving around economic planning. The story of the IRI thus reflects a shift in the approach to social engineering, from being a question of industrial relations to becoming a matter of economic planning. The present article also tries to answer the more precise question why some 20 Swedes first joined and then abandoned the organization.
\end{abstract}

Keywords: Mary van Kleeck - Kerstin Hesselgren - IRI-social engineering - scientific management - industrial relations-economic planning

In 1925 the International Industrial Relations Institute (IRI) was established at a congress of welfare and personnel workers in Holland. At first the organization focused attention on scientific management and industrial relations but during the Great Depression its activities began to center upon economic planning. The IRI was dominated by Mary van Kleeck from the United States and Mary L. Fleddérus from Holland and its radicalization reflected the ideas developed by van Kleeck, who became a dedicated advocate of Soviet style planning.

One of the initiators of the IRI was a Swedish industrial welfare worker, Signe Fredholm, and its first president was Kerstin Hesselgren, Sweden's first female factory inspector and member of parliament. The organization had about 20 Swedish members around 1930 but over the next couple of years these fell away. The IRI continued to function until after World War II. In this article, however, the focus will be on the first 
ten years of the IRI, when it was enjoying its heyday and basked in the attentions of Swedes inhabiting the world of industrial relations. ${ }^{1}$

The story of the IRI and its Swedish connection forms an interesting, but largely neglected chapter in labor history. Bruce E. Kaufman, in his recent and massive book on industrial relations, characterizes the IRI as "a remarkable but scarcely known organization" (Kaufman 212). The story has two particularly interesting aspects. Firstly, it reflects the transformation of social engineering from being an issue of industrial relations to becoming a matter of economic planning. Secondly, it tells something about the American influence on Sweden. The more precise question to be answered is why a number of Swedes first joined and then abandoned the IRI.

The present article introduces van Kleeck and Hesselgren briefly, summarizes the activities of the IRI with a focus on its Swedish members and attempts to answer the question why the Swedes joined and abandoned the IRI.

\section{Mary van Kleeck}

The remarkable career of Mary van Kleeck (1883-1972) has been saved from oblivion thanks to researchers like Guy Alchon (1985, 1991, 1992, 1999) and John M. Jordan (1994). Moreover there is an extensive Mary van Kleeck archive at Smith College in Northampton, Massachusetts, where several unpublished biographical essays about her can be found.

Mary van Kleeck grew up in New York and was educated at Smith College. She devoted her early career to the study of women in industry

1. This article forms part of a project on American welfare capitalism and social engineering, financed by the Jan Wallander and Tom Hedelius foundation. It is based mainly upon archive material: the Mary van Kleeck papers (MVK) at Social Work Archives/Sophia Smith Collection at Smith College, Northampton, Massachusetts; editorial material relating to Survey at the Social Welfare History Archives at University of Minnesota, Minneapolis, and Kerstin Hesselgren's papers at the Royal Library (Kungliga Biblioteket, KB), Stockholm, and (including her diary) at Göteborg University Library (GUL). I am especially grateful for help received from Kara M. McClurken at the Social Work Archives, David J. Klaassen at the Social Welfare History Archives, Elisabeth Hammarberg at Göteborg University Library, and Margareta Damm at Göteborg University. 
and became director of industrial studies at the Russell Sage Foundation - a position she retained for about 40 years. In the 1920s she became a leading figure in both the Taylor Society and the army of planners mustered by Secretary of Commerce Herbert Hoover. Like many other Taylorites she saw "the scientifically managed firm as a model for the wholesale reorganization of society" (Nyland and Rix 307).

One of van Kleeck's creations was the IRI, which she dominated in partnership with Fleddérus; it was "a two-woman transoceanic operation" (Jordan 193). The organization exerted its influence through conferences and congresses and reached its high water mark at the World Social Economic Congress held in Amsterdam in 1931, where van Kleeck "began her long career as staunch friend and fellow traveller of Stalin's Soviet Union" (Alchon 1991, 12). She appeared as a radical critic of Franklin Roosevelt's New Deal and her criticism culminated in an address entitled "Our Illusions Regarding Government," in which she urged an audience of American social workers to reject capitalism and private ownership and embrace a socialized, planned economy (van Kleeck 1934, Springer). Alchon $(1992,1109)$ reminds us that for a while van Kleeck contemplated labeling her activities as social engineering, while Jordan considers that "her version of social engineering might well be titled socialized engineering" (197-98).

Depression, dictatorship, and war did not dampen van Kleeck's faith in science and experimentation. "Indeed, it may be said of every nation of the world today that it is a vast economic laboratory," she proclaimed in a lecture before the American Sociological Society after World War II (van Kleeck 1946, 505). She persisted in advocating Soviet style socialism and in 1953 was summoned to committee hearings by Senator Joseph McCarthy. She spent the last decades of her life out of the public eye with her life-long friend Fleddérus.

\section{Kerstin Hesselgren}

Kerstin Hesselgren (1872-1962) was educated as a sanitary inspector at Bedford College in London. In 1913 she was appointed as the first female factory inspector in Sweden, a position she retained until 1934. 
She was also a lecturer in industrial health at the School for Social and Municipal Work (Socialpolitiska institutet) in Stockholm and acted for many years as a Swedish expert or delegate to the International Labour Organization (ILO) congresses and in the 1930s as a delegate to the League of Nations. In 1921 she was the first woman to be elected to the first chamber of the Swedish Riksdag, where she adopted the role of liberal maverick, earning herself the occasional nickname of "Kerstin the first" (see e.g. Gustafsson, Hamrin-Thorell et al., and Lindblad).

Hesselgren was an important source of inspiration for many women employed as welfare and personnel workers in Swedish industries. She founded and for many years chaired an association for welfare workers in industry and business (SAIA). She regarded such workers as the extended arm of factory inspection in the workplaces.

Hesselgren became aware of van Kleeck and was impressed by her as early as 1919, when she attended a Washington conference on women in the workplace. On October 28 she heard van Kleeck lecture on "The Spirit of Democracy" and took notes of the event in her diary. It may not be unreasonable to infer that the impression van Kleeck made on Hesselgren on this occasion laid some of the groundwork for Hesselgren's later involvement with the IRI.

\section{Formation of the IRI}

The idea of forming an international organization to promote human relations in industry came to the fore in 1922 at the First International Conference on Industrial Welfare at Château d'Argeronne in Normandy, France, where about 50 personnel workers had gathered to discuss their wartime experiences. According to Ruth Oldenziel the participants were mainly women who had been disappointed with the State as a vehicle of reform and therefore decided to join forces in a non-governmental organization (Oldenziel 325). At this conference an interim committee of nine people from different countries was formed with Marie Diemer of France as chairman, and Mary Fleddérus of Holland and Brenda Voysey of England as honorary secretaries. Representing Sweden was Signe Fredholm, a welfare worker from Malmö (Report 1925, 16-17). The committee met 
twice, at Mont Pélerin, Switzerland, and Château d'Argeronne, and published a report on "The International Development of the Industrial Welfare or Personnel Movement" in the International Labor Review 1924.

In June 1925 about 150 representatives from 20 countries and various walks of industrial life came together at The International Industrial Welfare (Personnel) Congress in Flushing, Holland, for the purpose of establishing an organization bearing the long-winded name of the International Association for the Study and Improvement of Human Relations and Conditions in Industry. Later on this title was changed to the International Industrial Relations Institute (for the Study and Promotion of Satisfactory Human Relations and Conditions in Industry). The association was to organize an international congress every third year and would serve as a meeting place for individual actors in the industrial arena managers, personnel workers, psychologists, physicians, engineers, foremen, employees, trade union leaders, factory inspectors. ${ }^{2}$

One recurrent theme at the 1925 congress was the ambition to remove "feudal" remnants from industrial welfare work. Ernst Hijmans, an "efficiency engineer" from Holland, pointed out that welfare work had been associated with paternalism and anti-unionism in some cases. No wonder workers were suspicious. "Thus it is today that the real well-meaning employer tries his best to hide all sentiment and to talk 'strictly business' when he tries to do something for his workers." This attitude must also permeate personnel work: "The training of Welfare Workers should be entirely directed towards this view of social service as 'business.' It should bar all dilettantism [...]" (Report 1925, 326, 328).

At this congress reports on conditions in 21 countries were presented. Kerstin Hesselgren and Anna Johansson-Visborg, socialist and trade union activist, reported on Sweden. Hesselgren cited experiences at ironworking establishments, where the old paternalistic system was being replaced by modern methods along American lines, and the Saving Fund Movement, another creation of American origin. She concurred in the opinion that welfare work was a regular feature of the production process:

The main difference between our modern Industrial Welfare Work and the old philanthropic one is, that it is done not only for, but with the help of those concerned and that 
it is considered a part of production. The growing recognition of Welfare Work expresses to my mind the opinion that the future development of industry depends not only on technical inventions and sufficient supply of labor, but also on the development of the workers as individuals. (Report 1925, 202-03)

Johansson-Visborg emphasized the importance of women forming their own trade unions and spoke of social and hygienic improvements in the brewing industry, where she herself worked as a link between employees and employers. Hesselgren also gave a lecture on the training of industrial welfare workers in Sweden and deplored the fact that employers had not yet understood the need for such training (Report 1925, 208, 446-48).

Hesselgren was elected president of the organization, an event recorded in her diary (26 June) as "something incredible." Alongside her she had three vice-presidents: Cees van der Leeuw, an industrialist from Holland, Renée de Montmort of France, and Louise Odencrantz of the US. Mary Fleddérus and Else Züblin-Spiller of Switzerland were elected honorary secretaries, Brenda Voysey organizing secretary, and Dorothy A. Cadbury of England treasurer. Together with representatives from each participating country these members of the board constituted a council. Swedish members were civil engineer Elis Bosaeus and Signe Fredholm, with Johansson-Visborg and Sigrid Göransson, social secretary at an ironworks, as adjoined members (Report 1925, 486-87, 490). It was decided that the new organization would have its headquarters in Zürich.

\section{Industrial Relations}

In July 1926 Hesselgren was acting chairman at an IRI council meeting held at Rigi-Scheidegg in Switzerland. It was decided that each country should be represented on the council by four people (two "reporters" and two "proxies") and that the headquarters should be moved to Holland. Three resolutions were adopted, stating that scientific management must take the human factor into consideration, that industry must eliminate all unnecessary fatigue, and that industrial welfare work must go hand in hand with factory legislation and inspection. ${ }^{3}$ 
At this meeting Sigrid Göransson acted as Swedish reporter. She noted that "scientific methods" had not yet aroused much interest in Sweden. There had been some experiments but no specific institution was acting as a driving force. Some lectures on scientific management were given as part of the education of technical engineers, but employers were more interested in the training of foremen. ${ }^{4}$

It seems as if relations between the formal IRI leader Hesselgren and the de facto leaders, Fleddérus and van Kleeck, were under some strain. In 1927 Fleddérus wrote in a letter to Hesselgren that "I [...] do not understand what you, or others, mean when you refer to the 'clique system' and I would be glad to know."5

A council meeting and summer school on "The Elimination of Unnecessary Fatigue in Industry" took place at Baveno on Lake Maggiore, Italy, in June 1927. 51 participants from 15 countries were present; van Kleeck was not among them. Hesselgren represented Sweden along with Elisabeth Johansson and Ester Låftman, personnel workers at the Tobacco Monopoly (Report 1925, 125-29). An executive committee meeting on the finances of the organization was tumultuous and Hesselgren wrote in her diary (27 June) that she became so angry that she could not sleep. Following the wrangle, Züblin-Spiller resigned as secretary and Hesselgren said she would not be available for a further term as chairman. The executive committee met again in Stockholm in January 1928, where Hesselgren and Cadbury made it clear that they were not willing to continue as IRI officers. ${ }^{6}$

The first triennial IRI congress took place at Girton College in Cambridge, England, June 28 to July 3, 1928, with 150 participants from 20 countries. The theme of the congress was "Fundamental Relationships between all Sections of the Industrial Community." Signe Fredholm gave an account of organizations and practices on Sweden's labour market and described diverse meetings and educational activities (Report 1928 I, 262-64). Lectures by Paul U. Kellogg, editor of Survey magazine, and Hesselgren on public opinion and industrial relations attracted attention.

4. MVK, Box 52:9, "Report of the open meetings held in connection with council mecting July 10-15, 1926," 12.

5. KB, L55:3, Letter from Fleddérus to Hesselgren, March 7, 1927.

6. MVK, Box 52:10, "Tentative memorandum for members of the Committee on Nominations," March 2, 1928, and "Report of the Committee on Nominations," June 15, 1928. 
Hesselgren emphasized the difficulties in understanding each other experienced by different groups both in industry and elsewhere. Nonetheless she was hopeful of the future and pleaded for cooperation: "There is a new demand for collaboration, for better relations between all sections in industry, which needs to be understood by public opinion" (Report 1928 II, 118-22). After the congress Kellogg wondered, in view of the American principles and practices that had been presented and caught the imagination of Europeans: "Can they learn the secrets of our magic lamps of efficiency?" (Kellogg 136).

Van Kleeck summarized the experiences and ideas exposed to view during the congress and stressed the importance of applying scientific methods to industry: "Unless the methods of science, which alone can reveal laws and sequences of cause and effect, be used, we cannot safely establish practice and procedure."7 According to her diary (July 2) Hesselgren felt this summary to be brilliant. Typical of the declarations to be found in the congress material is the following:

As industry is growing, so man must grow if he is to master it and use it as a social force. The fundamental idea of the I.R.I. is that it is not sufficient to take the narrow view of the industrialist who merely wants to increase production, or the hazy view of the sentimentalist who would ignore production and economic realities. Man is as real as machinery; machinery is as real as man. There must be adjustment and not only adjustment - for that is bound to take place - but intelligent adjustment, involving an understanding and mastery of economic forces to serve the world - the world of men and women. ${ }^{8}$

At the Cambridge congress Hesselgren resigned as president and Cadbury as treasurer. They were replaced by van der Leeuw and Charles E. Jacob, a businessman from Ireland, respectively. Van Kleeck, Fleddérus and Erich Lübbe, chairman of a works council in Germany, were elected vice-presidents. 42 people from 15 countries were elected to the council, among them four Swedes: Fredholm, Göransson, Hesselgren and Johansson-Visborg. ${ }^{9}$ The Swedish delegation to the congress consisted of six people in all: Märta André of the School for Social and Municipal Work, Ida Fischer, assistant to Hesselgren at the factory inspectorate,

7. MVK, Box 54B:14, "Survey of Report of 1928 Cambridge (England) Congress" (undated), 7, 11.

8. MVK, Box 54B:14, "Survey of Report of 1928 Cambridge (England) Congress," 2.

9. MVK, Box 54B:14, "Communication for Publication," "Minutes of General Meeting held at Cambridge, England, on Saturday, June 30 $30^{\text {th }}$, and Monday, July $2^{\text {md }}$, 1928" (September 1, 1928). 
Fredholm, Hesselgen and her sister Ingrid Hesselgren, personnel worker at the Tobacco Monopoly, and Ellen Östrand, a teacher. ${ }^{10}$

A 1929 summer meeting at Schloss Elmau in Upper Bavaria, Germany, on "Methods of Promoting Satisfactory Human Relations in a Scientifically Organised Industry" revolved around rationalization, scientific management, unemployment and the need for raised standards of living. Science was mooted as the solution to mounting economic difficulties. 63 members from 15 countries participated. Only one was from Sweden, Tilly Neovius, private secretary to a managing director." Fleddérus had tried in vain to persuade Hesselgren to attend the meeting. ${ }^{12}$ The following year Hesselgren had much to do and excused herself to Fleddérus for not having had time to promote the IRI in Sweden. Fleddérus was conciliatory and inquired whether Stockholm or Copenhagen might be a suitable venue for the next IRI congress. ${ }^{13}$

\section{Soviet Style Planning}

The world was plunging deeper and deeper into economic chaos. More and more minds were being invaded by notions of economic planning. To the IRI, which had devoted energy to science, efficiency, and mutual adjustment of all elements in production, the pieces seemed to be falling into place. The theme of the second triennial congress, entitled "World Social Economic Congress" and located in Amsterdam, August 23-29, 1931, was "Social Economic Planning - the Necessity for Planned Adjustment of Productive Capacity and Standards of Living." The invitation to the congress said:

Planned adjustment is a co-operative task, and the rapid growth of interdependence which is making all nations suffer together is at the same time the occasion for all nations and all groups to act together towards a solution. If one group imposes its lim-

10. MVK, Box 54B:16, "List of Persons Present." Ingrid Hesselgren was not a member of the IRI.

11. MVK, Box 55:1, "1929 Discussion Meeting. List of Participants"; Box 55:3, "For Immediate Release" (July 5,1929$)$.

12. KB, L55:3, Letter from Fleddérus to Hesselgren, May 7, 1929.

13. KB, L55:9, Letter from Hesselgren to Fleddérus, March 22, 1930, and L55:3, Letter from Fleddérus to Hesselgren, April 10, 1930. 
ited interest upon another, if output be unreasonably restricted by labor, if prices be held artificially high by monopolistic business, or if they be forced too low by destructive competition, if governments limit the contribution of their national areas to the world's economic life, balance is disturbed for all. On the other hand, if all can act in the light of common knowledge and toward a common purpose, a synthesis of fact and aspiration may emerge as a new lead in international economic policy. (Fleddérus xviii)

The emphasis upon planning aroused concern among members. At the end of April 1931 Hesselgren received a letter from Dora Schmidt, a colleague of Züblin-Spiller, who declared that the Swiss members had been invited to a meeting to discuss if they were to attend the Amsterdam congress. Schmidt thought it important to discuss social economic planning but was of the opinion that the IRI had moved far beyond its original purpose, at the same time neglecting important issues which the members were qualified to discuss. Schmidt asked for Hesselgren's opinion and whether the Swedes intended to attend the congress. ${ }^{14}$ Hesselgren replied that she had not been able to meet her delegation to discuss the matter. Her own point of view was the following:

I do not think, however, that we can attend the congress with a delegation. I have the impression that our members find this theme too scientific. The development of these last years has moved the I.R.I. far away from its original purpose and I have great difficulties retaining our members in the organization. Almost all of them are social workers and they have nowadays scanty space within the I.R.I. There are some new members, not belonging to the organization of social workers, but there is no unity; they are all too far from one another and nobody has the time to tie them together. We are in Sweden somewhat fed up with all these international associations and to get people to join a new association requires a lot of work. The present I.R.I. is certainly a new association, the questions to be discussed are, as you say, very interesting and important, but they are of the concern of other people and from our side probably only one or two people and certainly no delegation will attend. For my own part I still hope to be able to go there $[\ldots] .^{15}$

At the Amsterdam congress scientific management in the United States and Europe was presented by Harlow S. Person, managing director of the Taylor Society in New York, and Hugo van Haan of the International Management Institute in Geneva, respectively. The potential for economic planning in different countries was examined. The Russian econo- 
mist Valerian V. Ossinsky, assisted by some colleagues from Gosplan, gave an account of planning experiences in the Soviet Union; it seems to have been the first time a Soviet delegation had reported on the Russian five-year plans at an international meeting. Hesselgren had been announced as a speaker, but did not in fact appear in that capacity. She was, however, present at the congress with a few other Swedes: Margret Borelius, a student, Ellen Carlson, personnel worker of a department store, and Erik Falk, managing director of a metal-processing company. ${ }^{16}$

How IRI discussions at Amsterdam were expanded beyond personnel work and scientific management within the confines of single companies into the large-scale arena of societal planning is explained to some extent by van Kleeck in an article of 1931:

The second topic on the program, "Principles and Practicability of Economic Planning," centered about the principles and practice of scientific management in the United States and in Europe. Here experience in planning was shown to be limited for the most part to a workshop under homogeneous control, and the question raised was whether it is possible to extend the principles of scientific management in actual practice beyond the limits of individual control and to develop such forms of cooperative self-government in industry as shall make planning possible on a national and even international scale without changing the system of individual ownership. (van Kleeck 1931, 268)

The IRI's plans became increasingly ambitious. At the congress in Amsterdam an interim committee was constituted to establish a "World Commission for the Study of Social Economic Planning" with the intention of laying out "a general social economic plan for world production and world distribution"! The committee consisted of van Kleeck (chairman), Fleddérus, van der Leeuw, and a German businessman. It concluded that planning could not solve the ongoing crisis, but could furnish guidelines for the reconstruction of the world economy. Since the depression involved many countries national economic planning was not enough. A "world view" was needed as a basis for national planning. The commission would consist of economists and social scientists and would gather statistics of the world's productive capacity, study standards of living, examine principles and procedures for increased control over eco- 
nomic processes, and collate experiences of national and industrial planning, especially from the Soviet Union and Italy. ${ }^{17}$

IRI furthermore planned some organizational changes and intended to exchange "Association" for "Institute" in its name. Hesselgren gave her opinion in letters to Fleddérus and Frieda Wunderlich of the IRI. She said she had difficulties grasping the difference between "Association" and "Institute." However, she had discussed the matter within the SAIA and, despite lack of time for and interest in the question, it had been decided that the changes could be approved of. SAIA would until further notice pay its membership fee and individual members could be expected to do likewise. The letter to Wunderlich was quite gloomy: "Few of our members have any interest in the I.R.I. - the language barrier and the long journeys also make things difficult for us." The letter to Fleddérus was, however, rather hearty: "I hope that the new kind of association will be prosperous in its work and I wish it every luck." About the Amsterdam congress it was said: "In many ways it was a great success and you are all to be congratulated." In a letter to Annibale Correggiari in Italy the message was also rather optimistic: "I wonder how you find the change in I.R.I. - it may proove [sic] good. I suppose it has to be tried as things are now." A letter to Adele Beerensson in Germany was less optimistic: "I.R.I. has, however, been transformed into an institute for investigations and the like and can consequently not serve as an international association of social workers." 18

A regional study conference on "Social Economic Planning" was held in New York in late 1934. The question put before the participants was this: "What kind of economic planning can end unemployment, establish security, and raise standards of living in proportion to productive capacity?" The answer was given in a volume of conference proceedings, On Economic Planning, published in 1935. There is ground for pondering a little upon this volume, since it clarifies how far the IRI had advanced along the road of economic planning.

17. MVK, Box 55:14, "Proposal for the Establishment of a World Commission to Study Social Economic Planning," December 14, 1931, and "Interim Committee of 1931 World Social Economic Congress."

18. GUL, A14, II: 57, Letter from Hesselgren to Fleddérus and Wunderlich, February 1; to Correggiari, February 25; and to Beerensson, May 28, 1932. Quotations in German translated into English. 
Editors van Kleeck and Fleddérus declare in the preface that every phase of world history has its problems: "In our time it is the problem of planning our plentiful economic resources for human use. Our technical equipment combined with electricity as a source of power has reached a capacity which exceeds individual control." Basically, there were two kinds of planning: the restrictive, fascist, which tried to preserve capitalism, and the expansive, socialist, which abolished capitalism and poverty.

Valerian Ossinsky, vice-chairman of the Gosplan, gave an account of huge progress under the Soviet five-year plans, following which attention was focused on the deplorable condition of the US. Harry W. Laidler of the US Socialist Party had no sympathy for the New Deal and Earl Browder, general secretary of the US Communist Party, radiated selfconfidence when he spoke of the miracles achieved in the Soviet Union due to the scientific thinking of Marx, Engels, Lenin, and Stalin. Now the scene was set for van Kleeck, who spoke of social economic planning in the US. The problem of freedom in a collectivist society was dealt with in the following way:

This is freedom in a collective sense made necessary by evolution itself, which moves from the individual through the collective to a higher life for the individual. This requires elimination of the "force" whereby society's institutions become instruments of exploitation of one group by another group, the power to exploit arising out of private possession of the means of production, which is clearly incompatible with a social economic plan for the welfare of the community as a whole. (van Kleeck and Fleddérus 242)

The process of planning was described as "the discovery of the laws of technical and scientific production for the maximum standards of living and for lifting the structure of culture and civilization progressively" (242). The planning must be carried out according to a time-plan. "It was wise in the Soviet Union to adopt a five-year plan for industrialization" (256). In the US case, van Kleeck had a ten-year plan in mind: an emergency period of one year, a three year period when existing productive capacity would be fully utilized, and a six year period of expansion through the liberation of "progressive forces." Van Kleeck ended her speech by urging American technicians to free themselves from the system "which creates obstacles to the application of science to human society" (263). Only one Swedish participant was present at this confer- 
ence, Märta Nordin, personnel worker at the Swedish Post Office and, later on, SAIA chairman. ${ }^{19}$

\section{The Next Ten Years}

In the autumn of 1936 there was a regional study conference in New York on "The Next Ten Years." On this occasion van Kleeck drew up plans for the future. Political developments had made it difficult for members from Europe to participate as before. Therefore the US had to shoulder a major responsibility. In future the IRI might have to perform its activities within regional groups communicating by other means than conferences. van Kleeck concluded by likening the IRI to "a watchtower before which all the phases we know as civilization must pass in the next ten years." 20 About 240 people participated in this conference, but none from Sweden. ${ }^{21}$

The annual report for 1935-36 called attention to the research group intended to deal with world-wide planning. It was hoped that this group would be able to constitute "a World Social Economic Center." "The IRI has always hitched its wagon to a star [...]."22

Conference activity was maintained despite all difficulties. In 1937 and 1938 there were summer conferences in the Hague. The IRI continued to aim for the stars and planned to open new headquarters in Mexico and possibly in China, India, and Africa. ${ }^{23}$ In 1938 and 1939 there were further conferences in Mexico City, New York, Washington, and the Hague.

World War II meant that the IRI, whose members and leaders were scattered around in belligerent countries, had to suspend most of its activ-

19. MVK, Box 56:2, "List of Members of IRI Regional Study Conference on Social Economic Planning, New York, November 23-27 and December 1, 1934."

20. MVK, Box 56:6, "The IRI Program in Its Second Decade, by Mary van Kleeck," November 30, 1936.

21. MVK, Box 56:6, "List of Registrations for IRI Regional Study Conference, New York, November 30, 1936."

22. MVK, Box 52:16, "Annual Report for the Working Year April 1, 1935-March 31, 1936."

23. MVK, Box 52:18, "Program of Work and Plan for Support and Development," March 1, 1938. 
ities. In May 1940 the Germans occupied Holland. In November 1942 they ordered the IRI headquarters to be destroyed and replaced by defense works. The parallel headquarters in New York continued "enjoying the hospitality" of the Russell Sage Foundation, and van Kleeck and Fleddérus continued making plans for the future. The war, however, more or less killed off their bold project. The last conference mentioned in van Kleeck's papers took place in New York in 1947.

\section{IRI Membership}

IRI had a number of prominent members - welfare capitalists like Henry S. Dennison, Edward A. Filene, and Owen D. Young, and economists such as Irving Fisher, E.R.A. Seligman, and Jan Tinbergen, who was elected to the board in 1936 on the suggestion of Fleddérus. ${ }^{24}$ Simon Kuznets was one of the speakers at the conference in New York in 1934. Consequently, the IRI had managed to engage two future Nobel laureates, Tinbergen and Kuznets. The membership figures are summarized in the following table:

Table 1: IRI membership 1926-1932.

\begin{tabular}{lcc}
\hline Year & Number of members & Number of countries \\
\hline 1926 & 149 & [ca. 20] \\
1927 & 241 & 26 \\
1928 & 344 & 27 \\
1929 & 391 & 31 \\
1930 & 403 & 29 \\
1931 & 432 & 29 \\
1932 & 432 & 29 \\
\hline
\end{tabular}

Source: MVK, Box 52:9, “Annual Report 1925/26”; Box 52:10, "I.R.I. Secretaries Report 1926-1927," "Secretaries Report 1927-1928"; Box 52:12, "Minutes of Executive Meeting, January 1929," Attachment No 1.a.; Box 52:13, "Annual report April 1 $1^{\text {st }} 1929$-March $31^{\text {st }}$ 1930," “Annual Report April 1" 1930-March 31 $1^{\text {st }}$ 1931"; Box 52:14, "Annual Report April 1' 1931-March 31 1932." 
At the beginning of 1929 ten countries had more than ten members: Great Britain 89, USA 65, Germany 42, Sweden 24, Austria 21, Holland 19, Switzerland 18, Italy 16, Finland and France 11 each. ${ }^{25}$ From 1933 it is difficult to find figures of membership - one can assume they were reduced. One reason, indicated by van Kleeck, could be that political developments (supposedly the rise of National Socialism) made international exchanges more difficult. Another reason could be that the radical message of planning and socialization did not resound well among some of the occupations represented among IRI members:

Table 2: Major occupational categories of IRI membership in 1930.

\begin{tabular}{ll}
\hline Proprietors, directors and managers & 84 \\
Personnel managers, IR counsellors & 80 \\
Economists, social scientists, psychologists & 42 \\
Officers of labour market organizations & 40 \\
Industrial welfare workers & 34 \\
Educationalists & 28 \\
(Other) government officials & 23 \\
Factory inspectors & 19 \\
Engineers & 18
\end{tabular}

Source: MVK, Box 53:6, "List of Members and Sustaining Subscribers, June 1930."

IRI was dominated by women, but, as Ruth Oldenziel has noted, although the organization was "firmly rooted in the women's movement" it "shifted away from a gender specific perspective" already in 1925 -i.e. already from the beginning $(330,336)$.

The above account of IRI activities has revealed some Swedish names, the foremost of course being Kerstin Hesselgren. The peak of the Swedish involvement with IRI occurred in 1929-31. Defections began in 1932-33 and by 1938 there was only one Swedish member: Märta Nordin. ${ }^{26}$ In all, 26 Swedes appear as having been connected with the IRI. Of these 21 were women: ten were industrial welfare or personnel workers, three (including Kerstin Hesselgren) worked for the female factaining Subscribers, June 1931," “Addendum to printed membership list, dated June 1931," August 31, 1932, "Resignations from April 1 1932 to March 31 1933 ," "Membership List, December 1938." 
tory inspectorate, three were pioneers of the women's trade union movement, two were teachers, one worked for the cooperative movement, one was a private secretary, and one a student. Of the five men, four were managing directors and one, Gösta Ekelöf, was a trainer of foremen. A majority of the Swedes - the personnel workers, female factory inspectors, and teachers - belonged to the SAIA group.

\section{Conclusion}

To begin with, the activity of the IRI revolved around professional industrial welfare work, then around the decisive role of experts, scientific methods, and "intelligent adjustment" of all interests within industry, and finally around planned adjustment of all groups and nations. Van Kleeck followed the tide of the times but advanced further than most. What she envisioned was nothing less than worldwide planning and socialization.

Why did a number of Swedes join the IRI between 1925 and 1931, and why did they withdraw thereafter? No exhaustive answers are to be found in the archives as regards the first part of the question but a probable scenario may be inferred. Kerstin Hesselgren was impressed by Mary van Kleeck at a conference in 1919. Hesselgren was probably in some way involved in the preparations leading to the formation of the IRI. Whether she inspired Signe Fredholm to take part in the preparations, or whether Fredholm acted on her own and then informed Hesselgren is impossible to know. When Hesselgren in 1925 became the first president of the IRI she attracted her circle of industrial welfare workers and female factory inspectors to the organization.

As regards the second part of the question the empirical evidence is more substantial. Already in 1927 there were tensions between Hesselgren and Fleddérus/van Kleeck, i. e. between the formal and the real IRI leaders. After a row over the organization's finances Hesselgren made it clear she did not want to be reelected as president. Thereafter, naturally enough, she seems to have taken a less active part in the IRI activities. In early 1931, when the IRI launched its social economic planning theme, there were some doubts among members, at least in Switzerland and Sweden. The IRI had embarked on a new road and the old members - the 
industrial welfare workers - had difficulties accepting the new course. Hesselgren, in letters to IRI leaders, conveyed the message that membership engagement was cooling off. Hesselgren herself had an ambivalent attitude towards the change of course; it seems as if she wanted to retain good relations to the IRI leaders after all. In 1932-33 the Swedish withdrawals began. Nonetheless the question of IRI membership was on the agenda at the annual meetings of SAIA up to $1937 .{ }^{27}$ Even if economic and political developments - characterized by autarchy and nationalism made things difficult for an organization devoted to an international exchange of ideas it seems obvious that the Swedes primarily withdrew because they lost interest or were repelled by the planning ideas launched by the IRI. Soviet style planning on a global scale could hardly have attracted company executives, industrial welfare workers, and factory inspectors, people who were interested in industrial relations (social engineering in its original sense) and not in political utopian schemes (social engineering in its transformed sense).

That certain members were puzzled by the development of the organization is clear. An IRI report from 1932 noted that "there are those among its Members who seem to be somewhat under the impression that the IRI has changed its course during the more recent years." The IRI leaders denied that any such change had occurred. They pointed to "the straight line of development which the IRI has followed from the year 1925 onwards," and claimed that "this development was a logical necessity." 28 According to Oldenziel the move towards planning occurred "when European thinkers dominated the discussion" $(326,335)$, a conclusion that seems somewhat doubtful in view of the dominating role played by van Kleeck and the doubts expressed in certain European camps.

What did the Swedes get from the IRI meetings, to bring home to Sweden? Unfortunately, this question is impossible to answer. The participants have left few coherent records, and most of the Swedish IRI members are forgotten today. Not even Hesselgren made much noise at home about her IRI involvement. She mentioned in a memoir sketch that she intended to write something about the history of IRI and how she came to

27. GUL, A14, II:58, Agenda for the annual meeting of SAIA in 1937. The archive of SAIA, which could have given more information on relations with the IRI, has probably been lost.

28. These quotations are from the brochure "Ten years I.R.I." by Mary Fleddérus. 
be elected chairman, but she appears never to have put this intention into effect. ${ }^{29}$ She did touch upon the IRI on a few occasions in the late 1920 s. In a lecture on "the human factor in industry" in 1928 she mentioned the IRI and its Cambridge congress, and said that "we have much to learn from America in this area, but the methods are not always applicable." She further stressed the importance of "cooperation between nations in this area so that one can advance along the same lines." ${ }^{30}$

\section{References}

Alchon, Guy. The Invisible Hand of Planning: Capitalism, Social Science, and the State in the 1920s. Princeton: Princeton University Press, 1985.

- "Mary Van Kleeck and Social-Economic Planning." Journal of Policy History 3.1 (1991): 1-23.

- "Mary Van Kleeck and Scientific Management." A Mental Revolution: Scientific Management since Taylor: Ed. Danicl Nelson. Columbus: Ohio State University, 1992.

- "Van Kleeck, Mary." American National Biography, Vol. 22. New York \& Oxford: Oxford University Press (1999): 224-26.

Fleddérus, Mary L., ed. World Social Economic Planning: Material Contributed to the World Social Economic Congress, Amsterdam, August 1931. The Hague \& New York: I.R.I., 1932.

Gustafsson, Ingemar. "Kerstin Hesselgren - den charmerande socialreformatorn." Från Gästrikland 1987. Gävle: Gästriklands Kulturhistoriska Förenings Meddelanden (1989).

Hamrin-Thorell, Ruth, Ingrid Gärde Widemar, Alva Myrdal, and Malin Bergman. Boken om Kerstin Hesselgren: En vänstudie. Stockholm: P.A. Norstedt \& Söners Förlag, 1968. Jordan, John M. Machine-Age Ideology: Social Engineering and American Liberalism, 1911-1939. Chapel Hill \& London: The University of North Carolina Press, 1994.

Kaufman, Bruce E. The Global Evolution of Industrial Relations: Events, Ideas and the IIRA. Geneva: International Labour Office, 2004.

Kellogg, Paul U. "I.R.I. for Short.” Survey 62 (April 15, 1929): 136-37.

Lindblad, Linnea. "Kerstin Hesselgren - nästan alltid först." Liberala pionjärer. In Håkan Holmberg, ed., Uppsala: Uppsala Publishing House, 2002.

Nyland, Chris, and Mark Rix. "Mary van Kleeck, Lillian Gilbreth and the Women's Bureau Study of Gendered Labor Law." Journal of Management History 6.7 (2000): 306-22. 
Oldenziel, Ruth. "Gender and Scientific Management: Women and the History of the International Institute for Industrial Relations, 1922-1946." Journal of Management History 6.7 (2000): 323-42.

Report of the Proceedings of the International Industrial Welfare (Personnel) Congress, Flushing, June 1925. Zürich: IRI, 1925.

Report of Summer School Held at Baveno (Italy) June 1927 on the Subject of the Elimination of Unnecessary Fatigue in Industry. The Haguc: IRI, 1927.

Report of First Triennial Congress Held at Cambridge (England) July 1928 on the Subject of Fundamental Relationships between All Sections of the Industrial Community, Section I. The Hague: IRI, 1928.

Report of First Triennial Congress Held at Cambridge (England) July 1928, Section II. The Hague: IRI, 1928.

Springer, Gertrude. "Rising to a New Challenge." Survey 70 (June 1934): 179-80.

"The International Development of the Industrial Welfare or Personnel Movement." International Labour Review 10.1 (July 1924): 48-58.

van Kleeck, Mary. "The Personnel Manager in the World Workshop." The Personnel Journal 10.4 (December 1931): 265-69.

- "Our Illusions Regarding Government." Survey 70 (June 1934): 190-93.

- "Towards an Industrial Sociology." American Sociological Review 11.5 (1946): 501-05

- and Mary L. Fleddérus, eds. On Economic Planning: Papers Delivered at the Regional Study Conference of the International Industrial Relations Institute (IRI), New York, November 23-27, 1934. New York: Covici, Friede, 1935. 